\title{
Cystic Adventitial Disease of the Popliteal Artery
}

\author{
G. J. T. LEWIS,* M.B., F.R.C.S.ED. ; D. M. DOUGLAS, † M.B.E., CH.M., F.R.C.S., F.R.C.S.ED. \\ W. REID, $\ddagger$ M.B., F.R.C.S.GLASG., F.R.C.S.ED. ; J. KENNEDY WATT,§ CH.M., B.SC., F.R.C.S., F.R.C.S.GLASG.
}

Brit. med. F., 1967, 3, 411-415

In 1954 Ejrup and Hiertonn recorded a case of stenosis of the popliteal artery caused by a cyst arising from the adventitia, and this case and three similar ones were described by Hiertonn, Lindberg, and Rob (1957) as "cystic degeneration of the popliteal artery." The cardinal features they described were those of a localized arterial disease of young adult males causing intermittent claudication of sudden onset, which was successfully treated by resection of the affected arterial segment with autogenous vein graft or arterial homograft replacement.

This condtion is rare, and of the 32 cases described in the literature 24 have involved the popliteal artery (Sutton, 1962 ; Hamming and Vink, 1965 ; and others). It has also been described in the external iliac artery (Atkins and Key, 1946 ; Jacquet and Meyer-Burgdorff, 1960), the radial artery (Parkes, 1961 ; Bäckström, Linell, and Ostberg, 1965), and the ulnar artery (Parkes, 1961), and Hiertonn (1966) mentions a case in which the lesion arose from a small branch of the popliteal artery.

This paper presents three additional cases affecting the popliteal artery and reviews the literature on the condition.

\section{Case 1}

A boy aged 13 presented at the peripheral vascular unit, Glasgow Royal Infirmary, in March 1964. The previous month, during a gym period at school, he felt a sudden cramping pain in the left calf, and subsequently experienced pain in the left calf and popliteal fossa which stopped him walking at 100 yards (90 metres), and which was relieved by rest. He also complained that the left foot was colder than normal and often became white.

On examination there was wasting of the left calf. The left common femoral pulse was normal, but the left popliteal, posterior tibial, and dorsalis pedis pulses were absent and there was pallor of the left foot on elevation. Oscillometry showed an absence of pulsation in the left calf but normal pulsation in the left thigh. The right leg was normal. A femoral arteriogram showed a smooth stenosis of the popliteal artery, $2 \mathrm{~cm}$. long, at the level of the femoral epiphysial line. The sural arteries arose from the stenosed area and the remaining vessels were normal.

In June the left popliteal artery was explored and found to be dilated immediately above the level of the knee joint, and though dissection caused marked proximal spasm the artery was otherwise normal. On incising the adventitia of the "dilatation," gelatinous material extruded from between the adventitia and media. The media and intima were normal and the arteriotomy was repaired with a vein patch. At the completion of operation normal pulses had returned to the leg.

In August 1966, 27 months postoperatively, he was symptomfree and there was no clinical abnormality of the leg.

\section{Case 2}

A man aged 42 presented at the peripheral vascular unit, Glasgow Royal Infirmary, in April 1964 with an 18-month history of

- McIntyre Research Scholar, Glasgow Royal Infirmary. Present address, The Medical Centre, Ararat, Victoria.

† Professor of Surgery, St. Andrews University. eripheral Vascular

Hospital, Glasgow. Unit, Glasgow Royal Infirmary and Belvidere
Peripheral Vascular Un Hospital, Glasgow. claudication in the left calf, discomfort behind the left knee, and numbness of the left foot on walking half a mile (800 metres). There was no other relevant history.

On examination the femoral, popliteal, and posterior tibial pulses were normal but the dorsalis pedis pulse was absent. In the left popliteal fossa there was a visible swelling which was poorly defined, non-pulsatile, and of rubbery consistency. He was admitted for arteriography in July, by which time his claudication was forcing him to stop at a quarter of a mile ( 400 metres) and the left popliteal and posterior tibial pulses were diminished. A left femoral arteriogram on two occasions failed to demonstrate the superficial femoral artery but a right femoral arteriogram was normal. Left phenol lumbar sympathectomy was performed and his claudication distance increased to more than one mile (1,600 metres) at a normal pace.

The popliteal cyst was thought to be a semimembranosus bursa, but at exploration in October it was found to arise from the anterior wall of the popliteal artery and there was no communica-

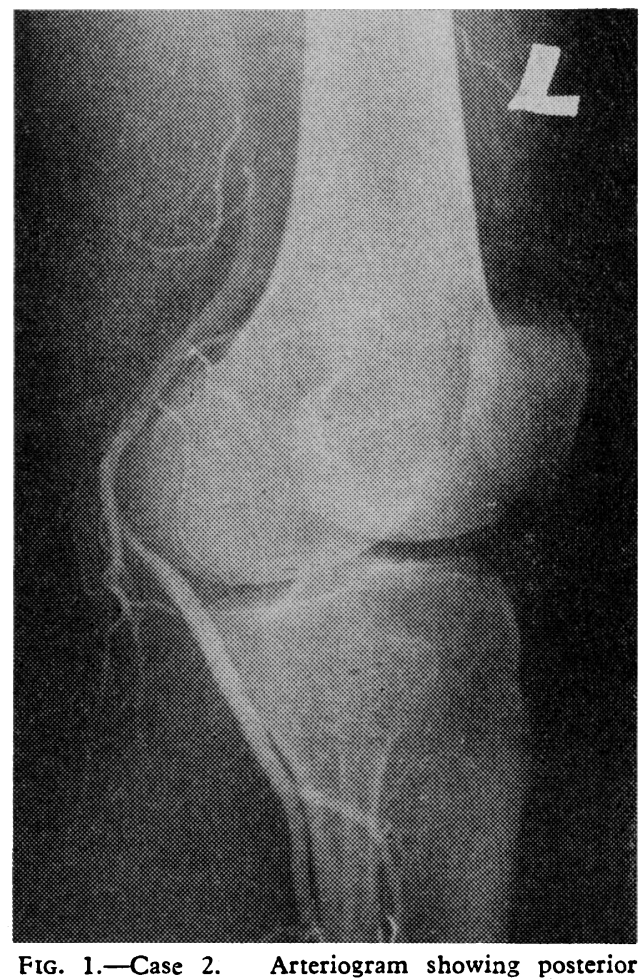
displacement of the popliteal artery due to the cyst.

tion with the knee joint. On incising the cyst a quantity of thick "jelly" extruded. The cyst wall was partially excised, after which the popliteal artery pulsated normally. Postoperatively the popliteal and posterior tibial pulses were normal, and he was asymptomatic for about one year.

He then had recurrence of claudication at 400 yards ( 365 metres), and on examination it was found that the popliteal cyst had recurred and was pushing the popliteal artery posteriorly so that the popliteal pulse was more easily palpable than normal and there was an audible bruit. Arteriography showed postero-medial displacement of the artery (Fig. 1). Ten millilitres of viscous homogeneous gel with a pinkish hue was aspirated from the cyst and he again became asymptomatic. 
When readmitted in August 1966 he was symptom-free, but a systolic bruit was audible over the easily palpable popliteal artery. At exploration the cyst lay anterior to the popliteal vessels at the level of the knee joint, being bound to the artery and vein by a tough outer sheath of fibrous tissue, which when divided revealed a translucent thin-walled mutilocular cyst. A plane of cleavage existed between the artery and cyst at all but one point where a stalk was present about $2 \mathrm{~mm}$. in diameter and length (Fig. 2), and here the cyst had to be cut off the artery. Histology of the specimen showed several cysts with fibrous connective-tissue walls which peripherally incorporated a very small amount of elastic fibres and with a lining of flattened fibroblast-like cells. Gradations from fully formed cysts to regions of myxomatous degeneration were present (Fig. 3). There was no evidence of neoplasm or inflammation.

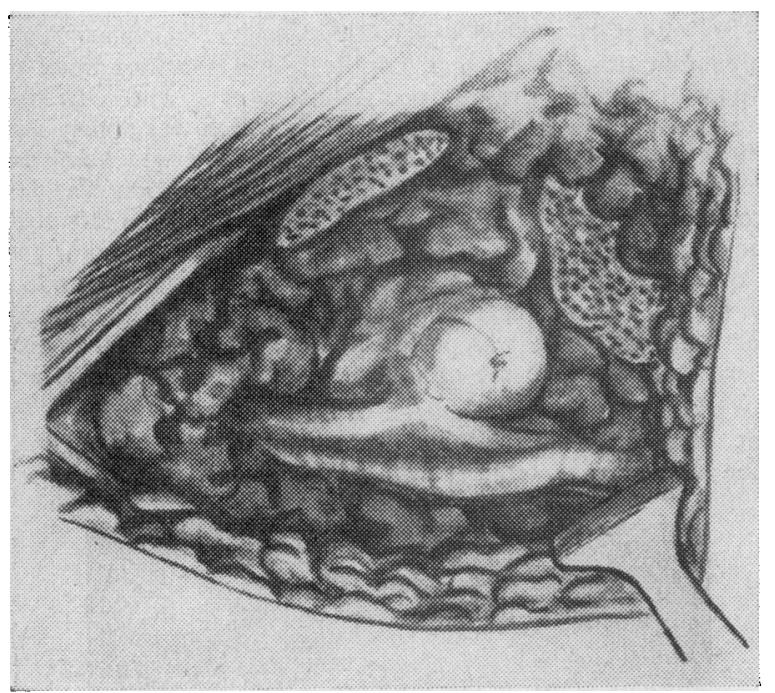

FIG. 2.-Case 2. Findings at operation. The medial head of gastrocnemius has been divided. The lobulated cyst arises from the anterior wall of the artery and the vein is crossing the artery at this level.

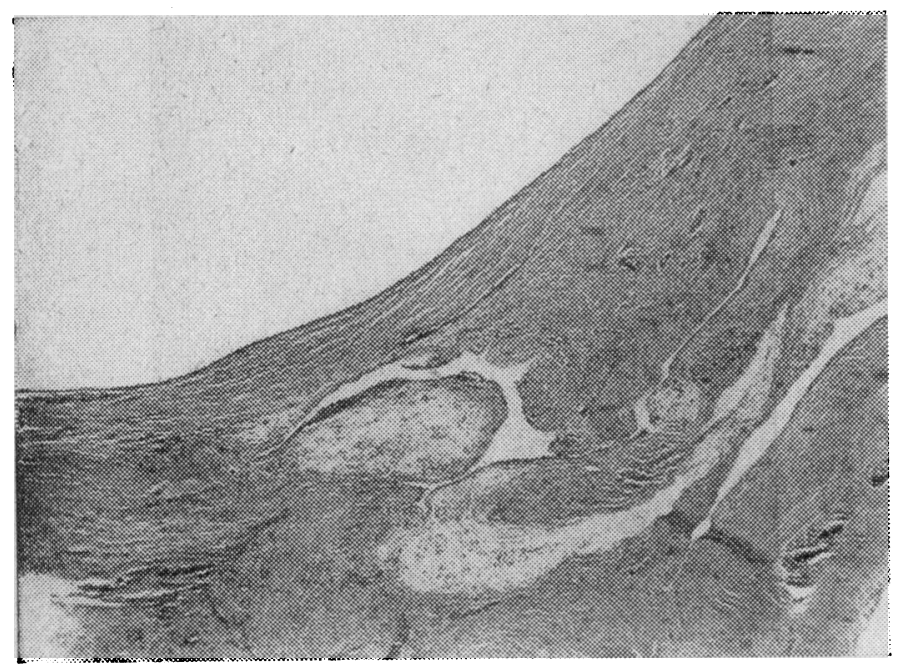

FIG. 3.-Case 2. Photomicrograph of cyst showing the connective-tissue wall and gradations from regions of myxomatous degeneration to fully formed cysts. (Haematoxylin and eosin. $\times 33$.)

\section{Case 3}

A man aged 55 attended the vascular clinic at Dundee Royal Infirmary on 20 July 1964 complaining of pain in the right calf on walking 100 yards (90 metres). The onset was gradual over a period of two to three months.

Examination of the right leg showed that all peripheral pulses beyond the femoral artery were absent whereas the pulses in the left leg were normal. Arteriography showed a stenosis of the popliteal artery, and a provisional diagnosis of early atheromatous change was made (Fig. 4).
On 24 July the popliteal artery was explored and a curious cystic mass of tissue involving the adventitia was disclosed. It measured $3 \mathrm{~cm}$. in length and $2 \mathrm{~cm}$. in width, and when it was dissected clear of the vessel the latter took on a normal appearance.

Postoperatively pulsation returned to his pedal vessels, his claudication disappeared, and arteriography showed a return of the vessel to a normal appearance (Fig. 4).

He returned to the vascular clinic on 26 April 1965, 10 months after operation, with a complaint of pain on walking. Arteriegraphy on 9 July showed slight narrowing and irregularity of the proximal

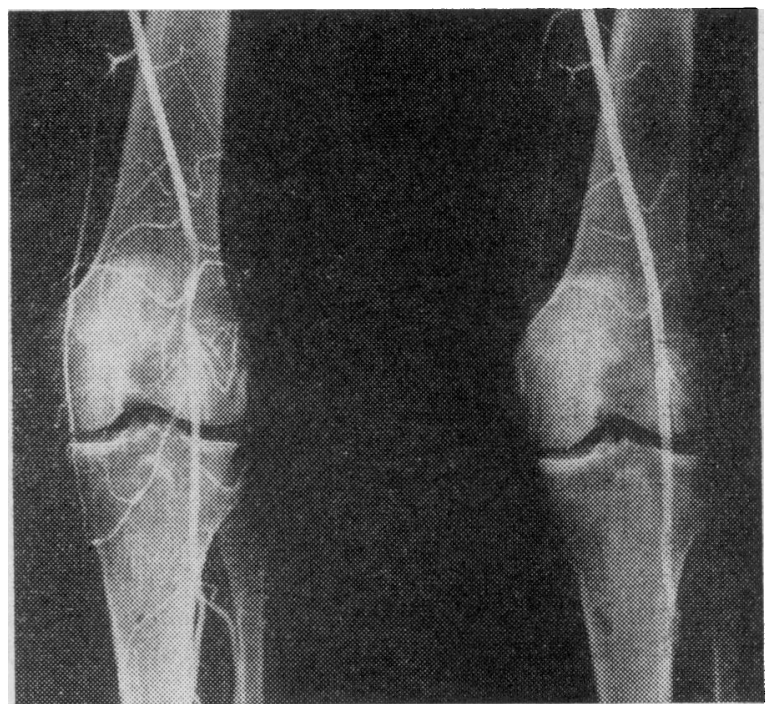

FIG. 4.-Case 3. Preoperative and postoperative arteriograms. In the preoperative picture there is striking demonstration of the development of the geniculate anastomosis around the knee
ioint. Postoperatively the arteriographic appearance is normal.

part of the popliteal artery. However, his distal pulses were normal, and when seen again on 17 September he was symptom-free.

The histology of the lesion (Fig. 5) was reported as: "The specimen was a ragged piece of tissue, 12 by 8 by $6 \mathrm{~mm}$., of firm consistency and yellowish-white cut surface. Sections show it to consist of varying cellular fibrous tissue in which there are many fairly sharply circumscribed areas of mucinous degeneration. Various stages in the process leading up to the end-stage of formation of "lakes" of metachromatic mucin can be seen. There would appear to be an initial overgrowth of the fibroblasts, then their gradual conversion to swollen cells with finely granular or foamy cytoplasm; and finally a bursting of the cells with release of the now mucinous contents. The process is akin to that which produces the 'ganglion' in association with the tendon or tendon sheath, but it appears, clinically, that the association was wholly

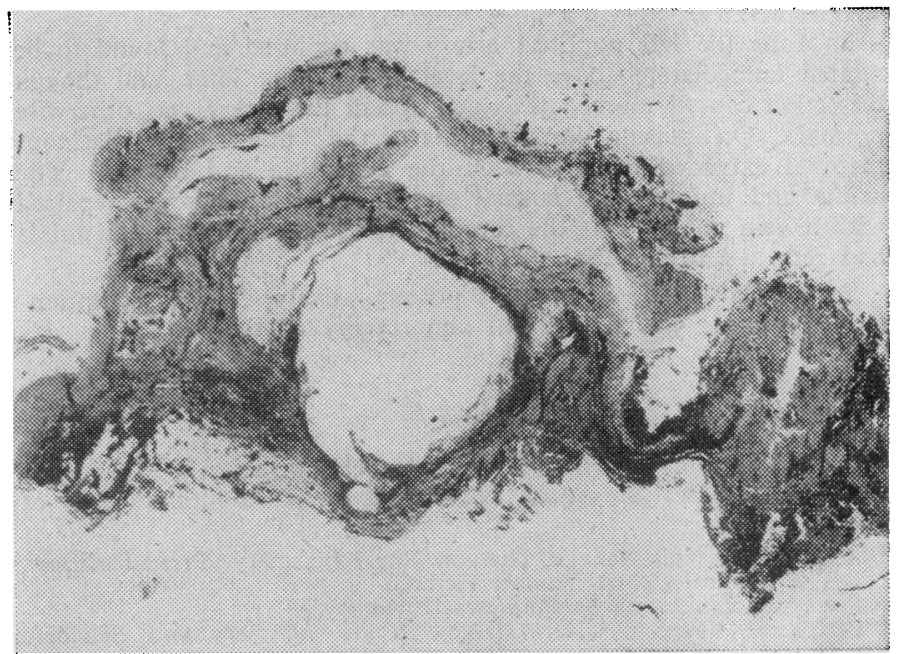

FIG. 5.-The whole section of the lesion removed at operation, showing the cystic spaces which were filled with gelatinous material. 
with the wall of the popliteal artery. It is thus difficult to go further than to classify this as " myxoma of arterial adventitia." "'

\section{Discussion}

Cystic degeneration of the political artery is a rare condition the cause of which is unknown. The incidence in the peripheral vascular unit, Glasgow Royal Infirmary, is approximately 1 in 1,200 of those patients presenting with claudication or 1 in 1,000 of those undergoing arteriography, an incidence similar to that reported by Hamming and Vink (1965). The sex incidence in the literature is eight males to one female, which approximates to the sex incidence of occlusion in the lower limb due to atherosclerosis. The three cases reported in females have all involved the popliteal artery. The average age of affected males is 36 years and of females 49 years.
The aetiology of the lesion is obscure. It seems unreasonable to ascribe its development to degenerative changes in an atherosclerotic or otherwise abnormal arterial wall, as our first patient (Case 1) was 13 years of age and Harris and Jepson (1965) described its occurrence in a boy of 11 years, and for this reason the title " cystic degeneration" appears to be a misnomer. Histology shows no evidence of haemorrhage, inflammation, or neoplasia, and the appearance is similar to that found in ganglia elsewhere. On the other hand, ganglia are most commonly found in the late teens and twenties (McEvedy, 1962), whereas this condition has its greatest incidence in the late thirties, a time when atherosclerosis is often developing.

The media and intima are usually intact and any damage to them is probably secondary (Hiertonn et al., 1957 ; Andersson, Gothman, and Lindberg, 1959). Harris and Jepson (1965) reported a significant amount of hydroxyproline present in the

Nature of Lesion and Results of Treatment in 24 Cases of Cystic Adventitial Disease of the Popliteal Artery

\begin{tabular}{|c|c|c|c|c|c|c|c|c|c|c|c|}
\hline $\begin{array}{l}\text { Case } \\
\text { No. }\end{array}$ & $\begin{array}{c}\text { Year } \\
\text { Reported }\end{array}$ & Author & Age & Sex & Onset & Arteriogram & Year & Operation Findings & Operation & Histology & $\begin{array}{l}\text { Condition at } \\
\text { Follow-up }\end{array}$ \\
\hline 1 & 1957 & $\begin{array}{l}\text { Hiertonn } \\
\text { et al. }\end{array}$ & 32 & $M$ & Gradual & Stenosis & 1953 & $\begin{array}{l}\text { Walnut-sized swelling, } \\
\text { blish in colour }\end{array}$ & $\begin{array}{l}\text { Resection and } \\
\text { autogenous vein }\end{array}$ & $\begin{array}{l}\text { Unilocular adventitial cyst. } \\
\text { Normal media and intima }\end{array}$ & $\begin{array}{l}\text { Patent } 11 \text { years } \\
\quad(1964)\end{array}$ \\
\hline 2 & 1957 & $"$ & 25 & $\mathbf{M}$ & Sudden & $\begin{array}{l}\text { Occlusion, } \\
3 \mathrm{~cm}\end{array}$ & 1955 & $\begin{array}{l}\text { Fusiform thickening } \\
6 \mathrm{~cm} \text {. long }\end{array}$ & Resection and & $\begin{array}{l}\text { Adventitial cyst. Partial media } \\
\text { necrosis }\end{array}$ & $\begin{array}{l}\text { Patent } 11 \text { years } \\
\quad(1966)\end{array}$ \\
\hline 3 & 1957 & ", & 24 & $\mathbf{M}$ & $"$ & Occlusion & 1954 & $\begin{array}{l}\text { Fusiform thickening } \\
9 \mathrm{~cm} \text {. long, bluish in } \\
\text { colour. Periarteritis }\end{array}$ & $\begin{array}{l}\text { homograft } \\
\text { Resection and } \\
\text { autogenous } \\
\text { vein graft }\end{array}$ & $\begin{array}{l}\text { Adventitial cyst communicating } \\
\text { with lumen and a double } \\
\text { lumen had developed dis- }\end{array}$ & $\begin{array}{l}\text { Patent } 10 \text { years } \\
\quad(1964)\end{array}$ \\
\hline 4 & 1957 & " & 32 & $\mathbf{M}$ & . & $\begin{array}{l}\text { Occlusion, } \\
6 \mathrm{~cm}\end{array}$ & 1956 & $\begin{array}{l}\text { Fusiform swelling } 7 \mathrm{~cm} \text {. } \\
\text { long, light pink in }\end{array}$ & $\begin{array}{l}\text { Resection and } \\
\text { autogenous }\end{array}$ & $\begin{array}{l}\text { tally. Medial calcification } \\
\text { Adventitial cyst. Normal } \\
\text { media }\end{array}$ & $\begin{array}{l}\text { Patent } 8 \text { years } \\
\quad(1964)\end{array}$ \\
\hline 5 & 1958 & $\begin{array}{l}\text { Tytgat } \\
\text { et al. }\end{array}$ & 47 & $\mathbf{M}$ & , & St_nosis & 1957 & $\begin{array}{l}\text { Pulsatile swelling } 5 \mathrm{~cm} . \\
\text { long with periarteritis }\end{array}$ & $\begin{array}{l}\text { Resection and } \\
\text { nylon graft }\end{array}$ & $\begin{array}{l}\text { Multilocular cyst in media and } \\
\text { adventitia communicating }\end{array}$ & $\begin{array}{l}\text { Occluded } 4 \text { months } \\
\text { later }\end{array}$ \\
\hline 6 & 1958 & $\begin{array}{l}\text { Patel } \\
\text { et al. }\end{array}$ & 50 & $\mathbf{F}$ & Gradual & ", & 1952 & Fusiform swelling & $\begin{array}{l}\text { Arteriotomy and } \\
\text { extrusion of gel }\end{array}$ & with lumen in two places & $\begin{array}{c}\text { Patent } 8 \text { years } \\
(1960)\end{array}$ \\
\hline 7 & 1959 & $\begin{array}{l}\text { Andersson } \\
\text { et al. }\end{array}$ & 48 & $M$ & Unknown & $\begin{array}{l}\text { Occlusion, } \\
8 \mathrm{~cm}\end{array}$ & 1959 & $\begin{array}{l}\text { Fusiform swelling } 8 \mathrm{~cm} \text {. } \\
\text { long }\end{array}$ & $\begin{array}{l}\text { Resection and } \\
\text { arterial } \\
\text { homograft }\end{array}$ & $\begin{array}{l}\text { Cyst between media and adven- } \\
\text { titia with a tiny communica- } \\
\text { tion with the lumen (thought } \\
\text { to be secondary). Degenera- } \\
\text { tive changes in media and } \\
\text { intima }\end{array}$ & $\begin{array}{l}\text { Patent } 7 \text { years } \\
\text { (1966) }\end{array}$ \\
\hline 8 & 1960 & Holmes & 42 & M & Suc!den & $\begin{array}{l}\text { Stenosis, } \\
\quad 4 \mathrm{~cm}\end{array}$ & 1957 & $\begin{array}{l}\text { Fusiform swelling } 3 \mathrm{~cm} \text {. } \\
\text { long }\end{array}$ & $\begin{array}{l}\text { Excision of cyst } \\
\text { with outer part } \\
\text { of arterial wall }\end{array}$ & $\begin{array}{l}\text { Cyst lined by degenerated } \\
\text { fbrous tissue and covered } \\
\text { by fibrin and fibrinoid } \\
\text { material }\end{array}$ & Patent 8 years later \\
\hline 9 & 1960 & $\begin{array}{r}\text { Delannoy, } \\
\text { Martinot }\end{array}$ & 38 & $\mathbf{M}$ & Unknown & $\begin{array}{l}\text { Stenosis, } \\
2 \mathrm{~cm}\end{array}$ & 1958 & $\begin{array}{l}\text { Fusiform swelling } 5 \mathrm{~cm} \text {. } \\
\text { long }\end{array}$ & $\begin{array}{l}\text { Incision of cyst } \\
\text { and extrusion }\end{array}$ & material & Patent 2 years later \\
\hline 10 & 1960 & Robb & 39 & M & Sudden & $\begin{array}{l}\text { Stenosis, } \\
3 \mathrm{~cm} \text {. }\end{array}$ & 1959 & $\begin{array}{c}\text { Transparent almond- } \\
\text { shaped cyst } 5 \mathrm{~cm} \text {. long }\end{array}$ & $\begin{array}{l}\text { Resection and } \\
\text { autogenous }\end{array}$ & $\begin{array}{l}\text { Adventitial cyst with flattened } \\
\text { endothelial cell lining }\end{array}$ & Unknown (1966) \\
\hline 11 & 1961 & $\begin{array}{l}\text { Ishikawa } \\
\text { et al. }\end{array}$ & 32 & M & . & Stenosis & 1959 & $\begin{array}{l}\text { " With periarteritis } \\
3 \mathrm{~cm} \text {. long }\end{array}$ & $\begin{array}{l}\text { vein graft } \\
\text { Excision of cyst. } \\
\text { (Lumbar gang- } \\
\text { lionectomy } 1\end{array}$ & $\begin{array}{l}\text { Multilocular cyst lined by } \\
\text { lamellar fibrous tissue }\end{array}$ & $\begin{array}{l}\text { Patent } 5 \text { years } \\
(1964)\end{array}$ \\
\hline 12 & 1962 & Chevrier & 26 & M & ," & $\begin{array}{l}\text { Stenosis with } \\
\text { posterior } \\
\text { displacement }\end{array}$ & 1961 & Swelling $2 \mathrm{~cm}$. long & Excision of cysts & Adventitial cyst & $\begin{array}{l}\text { Patent } 6 \text { months } \\
\text { later }(1961)\end{array}$ \\
\hline 13 & 1963 & Simon & 52 & $\mathbf{M}$ & " & Stenosis & 1962 & $\begin{array}{l}\text { "No thickening or } \\
\text { hardening" }\end{array}$ & $\begin{array}{l}\text { Resection and } \\
\text { Dacron graft }\end{array}$ & & $\begin{array}{l}\text { Patent } 16 \text { months } \\
\text { later }(1963)\end{array}$ \\
\hline 14 & 1963 & $\begin{array}{l}\text { Patel, } \\
\text { Cormier }\end{array}$ & 23 & $M$ & ", & ” & 1962 & $\begin{array}{l}\text { Fusiform bluish } \\
\text { swelling }\end{array}$ & $\begin{array}{l}\text { Resection of cyst } \\
\text { and periarterial }\end{array}$ & $\begin{array}{l}\text { Adventitial cyst with endo- } \\
\text { thelial lining }\end{array}$ & $\begin{array}{l}\text { Not seen since } \\
\text { operation }\end{array}$ \\
\hline 15 & 1963 & $\begin{array}{l}\text { Bliss } \\
\text { et al. }\end{array}$ & 40 & $\mathbf{F}$ & , & & 1962 & $\begin{array}{l}\text { Fusiform swelling } 5 \mathrm{~cm} \text {. } \\
\text { long with periarteritis }\end{array}$ & $\begin{array}{l}\text { sympathectomy } \\
\text { Incision of cyst } \\
\text { with extrusion }\end{array}$ & $\begin{array}{l}\text { Dense fibrous tissue with a few } \\
\text { elastic fibres }\end{array}$ & $\begin{array}{l}\text { Return of slight } \\
\text { claudication } 1966\end{array}$ \\
\hline 16 & 1963 & Lambley & 47 & $\mathbf{M}$ & , & & 1962 & $\begin{array}{l}\text { Fusiform bluish pulsat- } \\
\text { ing swelling } 5 \mathrm{~cm} \text {. } \\
\text { long }\end{array}$ & $\begin{array}{l}\text { of gel and biopsy } \\
\text { Resection and } \\
\text { Teflon graft }\end{array}$ & $\begin{array}{l}\text { Adventitial cyst with endothe- } \\
\text { lial celllining. Patchy medial } \\
\text { fibrosis and intimal thicken- } \\
\text { ing }\end{array}$ & $\begin{array}{l}\text { Occluded } 9 \text { months } \\
\text { but symptom- } \\
\text { free } 3 \text { years later } \\
\text { (1966) following } \\
\text { lumbar ganglion- } \\
\text { ectomy }\end{array}$ \\
\hline 17 & 1964 & $\begin{array}{l}\text { Barnett, } \\
\text { Morris }\end{array}$ & 56 & $\mathbf{F}$ & Gradual & Occlusion & 1963 & $\begin{array}{l}\text { Fusiform bluish swel- } \\
\text { ling } 5 \mathrm{~cm} \text {. long }\end{array}$ & $\begin{array}{l}\text { Arteriotomy with } \\
\text { extrusion of gel } \\
\text { and Dacron } \\
\text { patch }\end{array}$ & $\begin{array}{l}\text { Subintimal mucinous degenera- } \\
\text { tion }\end{array}$ & $\begin{array}{l}\text { ectomy } \\
\text { Patent } 2 \text { years } \\
\text { (1965) but } \\
\text { narrowed }\end{array}$ \\
\hline 18 & 1965 & $\begin{array}{l}\text { Harris, } \\
\text { Jepson }\end{array}$ & 11 & $M$ & Unknown & $\begin{array}{l}\text { Severe } \\
\text { stenosis }\end{array}$ & 1964 & Swelling in two parts. & $\begin{array}{l}\text { partial cyst } \\
\text { excision with }\end{array}$ & & Unknown (1966) \\
\hline 19 & 1965 & Mentha & 33 & M & Sudden & Stenosis & 1960 & $\begin{array}{l}\text { bluish, } 2.5 \mathrm{~cm} \text {. long } \\
\text { Diagnosis made by } \\
\text { aspiration of gel }\end{array}$ & $\begin{array}{l}\text { gel extrusion } \\
\text { Lumbar ganglion- } \\
\text { ectomy and cyst }\end{array}$ & & $\begin{array}{l}\text { Patent } 6 \text { years } \\
\quad(1966)\end{array}$ \\
\hline 20 & 1966 & Hansen & 56 & $\mathbf{M}$ & Gradual & Occlusion & 1963 & $\begin{array}{l}\text { Fusiform pulsating } \\
\text { swelling } 5 \mathrm{~cm} \text {. long }\end{array}$ & $\begin{array}{l}\text { aspiration } \\
\text { Partial cyst } \\
\text { excision with }\end{array}$ & Multilocular cys & $\begin{array}{l}\text { Patent } 3 \text { years } \\
\quad(1966)\end{array}$ \\
\hline 21 & 1966 & $\begin{array}{l}\text { Barnett } \\
\text { et al. }\end{array}$ & 61 & $M$ & Sudden & $\begin{array}{l}\text { Stenosis on } \\
\text { lateral view } \\
\text { only }\end{array}$ & 1965 & $\begin{array}{l}\text { Fusiform swelling } \\
3.5 \mathrm{~cm} . \text { long }\end{array}$ & $\begin{array}{l}\text { sion of gel } \\
\text { ion and } \\
\text { enous } \\
\text { graft }\end{array}$ & & \\
\hline 22 & 1967 & Case 1 & 13 & $M$ & , & $\begin{array}{l}\text { Only } \\
\text { Stenosis }\end{array}$ & 1964 & $\begin{array}{l}\text { Fusiform swelling } 3 \mathrm{~cm} . \\
\text { long }\end{array}$ & $\begin{array}{l}\text { vein graft } \\
\text { Arteriotomy with } \\
\text { extrusion of gel }\end{array}$ & $\mathrm{Nil}$ & $\begin{array}{l}\text { Patent } 2 \text { years } \\
\quad(1966)\end{array}$ \\
\hline 23 & 1967 & , 2 & 42 & $M$ & Gradual & $\begin{array}{l}\text { Stenosis } \\
\text { with } \\
\text { displace- }\end{array}$ & 1964 & $\begin{array}{l}\text { Lobulated translucent } \\
\text { cyst on one side of } \\
\text { artery }\end{array}$ & $\begin{array}{l}\text { Incomplete } \\
\text { excision (1964) }\end{array}$ & & Recurrence 1 year \\
\hline 24 & 1967 & 3 & 55 & $M$ & ". & $\begin{array}{l}\text { ment } \\
\text { Stenosis }\end{array}$ & $\begin{array}{l}1966 \\
1964\end{array}$ & $\begin{array}{l}\text { Gelatinous cystic mass } \\
3 \text { by } 2 \mathrm{~cm} \text {. }\end{array}$ & $\begin{array}{l}\text { Excision of cyst } \\
\text { in toto } \\
\text { Excision of cyst } \\
\text { in toto }\end{array}$ & Multilocular cyst & $\begin{array}{l}\text { Patent } 6 \text { months } \\
\quad(1966) \\
\text { Patent } 1 \text { year (1965) }\end{array}$ \\
\hline
\end{tabular}


gel and suggested that this indicated its origin from collagen tissue, but quantitative analysis of the protein of the gel from Case 2 does not support this view (see Addendum). Most authors-for example, Ishikawa, Mishima, and Kobayashi (1961)-have suggested that repeated minor trauma to the popliteal artery plays a significant part. The fact that the lesion is almost always in close association with the back of the knee joint and that gelatinous degeneration of the tendon sheaths in this region is common raises the possibility that regional factors may be concerned-for example, the range of movement of the knee joint and of the adjacent artery and tendons. But a more attractive theory might be the incorporation, during development, of mucin-secreting cells from the endothelium of the knee joint in the adventitia of the artery. These cells secreting small amounts of mucin over many years might eventually give rise to tense adventitial cysts which encroach on the lumen of the vessel.

The usual presenting symptom is intermittent claudication, which may be of gradual or sudden onset and may be accompanied by a cold white foot and pain. Sometimes the initial symptoms are episodic and the pain is atypical of claudication (Barnet and Morris, 1964 ; Hiertonn et al., 1957). The pulse pattern is variable, and in the two cases with " ischaemic rest pain" the lower-limb pulses were normal (Chevrier, 1962; Mentha, 1965), suggesting a neuritis from pressure on the popliteal nerves. Exercise or knee flexion may cause the disappearance of distal pulses (Ishikawa et al., 1961). A visible and palpable swelling (Case 2) has not previously been reported, though Lambley (1963) noted the affected popliteal artery to be more easily palpable than normal and Mentha (1965) recorded a bruit at the level of the stenosis.

The condition can usually be recognized by the typical arteriographic appearances, which show a localized lesion at or above the level of the knee joint in an otherwise normal popliteal artery. The lesion may cause stenosis, occlusion, or displacement of the artery. The stenosis is a smooth indentation of the arterial wall which may be one-sided or hour-glass in appearance, and which may vary in severity with the pulse wave (Jacquet and Meyer-Burgdorff, 1960) or posture (Bliss, Rhodes, and Rains, 1963). Similar stenotic appearances may be caused by a local atheromatous plaque, but post-stenotic dilatation has not been noted with cystic degeneration and in doubtful cases a lateral arteriogram may show irregularity. With adventitial cysts, lateral views may also show posterior displacement of the artery (Case 2) or a rigid arterial segment causing kinking of the artery when the knee is flexed (Ishikawa et al., 1961). Occlusion may be due to contact between the intimal surfaces of the artery (Hiertonn et al., 1957 ; Harris and Jepson, 1965), but more often it is due to thrombosis after severe stenosis. Once thrombosis has occurred, the arteriographic appearances resemble those of arteriosclerosis, though a smooth tapering-off at the limits of the occlusion (Andersson et al., 1959)-aply termed the "scimitar" effect by Harris and Jepson (1965)-may suggest cystic pressure.

At operation the lesion most commonly appears as a welldefined lump, bluish in colour, non-pulsatile, elastic in consistency, and of variable length $(2-9 \mathrm{~cm}$.), and it may lie to one side of, or partially or completely invest, the artery. It has also been described as a dilatation of the artery (Simon, 1963) as yellowish brown in colour (Ishikawa et al., 1961) and as a pulsatile lump (Lambley, 1963 ; Tytgat, Derom, and Galinsky, 1958). Dense periarterial adhesions similar to those found in Case 2 have been reported by other authors (Hiertonn et al., 1957 ; Robb, 1960 ; Tytgat et al., 1958 ; Ishikawa et al., 1961 ; Bliss et al., 1963).

The type and outcome of surgical treatment in 24 cases are summarized in the Table; all the cases appear to have had excellent initial results. The late results in 13 of them have been obtained by correspondence with previous authors. When a stenosis is present, incision of the cyst with extrusion of the gel or excision of the cyst in toto (with or without arteriotomy) may give a satisfactory long-term result, but when occlusion is present arterial resection with autogenous vein graft should be performed, as synthetic grafts at this level are prone to occlusion. Case 2 supports the view that recurrence may follow partial excision of the cyst (Bäckström et al., 1965), and Rains (1966) writes of the recurrence of claudication four years after incision alone. In contrast, in one case the arteriogram returned to normal after lumbar ganglionectomy and cyst aspiration and the patient was symptom-free six years later (Mentha, 1966).

\section{Summary}

Cystic adventitial disease of the arteries is a rare and only recently recognized entity which most commonly occurs in the popliteal artery, causing intermittent claudication. Three further cases affecting the popliteal artery are presented.

The aetiology of the condition is obscure. The cyst containing gel may be unilocular or multilocular, and appears to arise from the arterial adventitia. Histology shows no evidence of haemorrhage, inflammation, or neoplasia. The absence of hydroxyproline in the gel is against an origin from collagen or elastin, and its occurrence in children is against degenerative changes in the arterial wall.

The typical clinical picture is of intermittent claudication of sudden onset in a young adult male. The pulse pattern is variable and the popliteal pulse may be absent or more easily palpable than normal, or an audible bruit may be present over it. Exercise or knee flexion may cause the disappearance of pedal pulses.

The arteriographic appearance is of stenosis, displacement, or occlusion at or above the level of the knee joint in an otherwise normal popliteal artery.

A review of the results of treatment indicates that after complete excision of the cyst (with or without arteriotomy) or arterial resection with autogenous vein-graft replacement the prognosis is excellent.

We wish to thank Mrs. J. Lewis for the operative illustration in Case 2 ; Dr. D. Raeside and Dr. George Howie for the excellent arteriograms; Dr. E. Walker and Dr. W. W. Park for the histological studies; and Mr. P. Kelly for some of the photographic reproductions. Finally, we thank all those previous authors who so kindly provided us with their long-term follow-up findings.

\section{REFERENCES}

Andersson, T., Gotham, B., and Lindberg, K. (1959). Acta radiol. (Stockh.), 52, 455

Atkins, H. J.' B., and Key, J. A. (1947). Brit. J. Surg., 34, 426.
Bäckström, C. G., Linell, F., and Ostberg. G. (1965). Acta chir. scand., $129,447$.

Barnett, A. J. (1966). Personal communication.

Dugdale, L., and Ferguson, I. (1966). Med. Ұ. Aust., 2, 355. - and Morris, K. N. (1964). Ibid. 2, 793.

Bartos, J. (1966). Langenbecks Arch. klin. Chir., 314, 177.

Bliss, B. P., Rhodes, J., and Rains, A. J. Harding (1963). Brit. med. F.,

Chevrier, J. L. (1962). Mém. Acad. Chir., 88, 261.

Delannoy, E., and Martinot, M. (1960). Ibid., 86, 824.

Evans, G. (1966). Personal communication.

Gothman, B. (1966). Personal communication

Gripe, K. (1963). Nord. Med., 70, 1381.

Hamming, J. J., and Vink, M. (1965). Ұ. cardiovasc. Surg., 6, 516.

Hansen, J. P. (1966). Acta chir. scand., 131, 171.

Harris, J. D., and Jepson, R. P. (1965). Aust. N.Z. F. Surg., 34, 265.

Hiertonn, T. (1966). Personal communication.

and Lindberg, $\mathrm{K}$. (1957). Acta chir. scand., 113, 72.

Rob, C. (1957). Brit. I. Surg., 44, 348.

Holmes, J. G. (1960). . Amer. med.

Ishikawa, K. (1966). Personal communication.

Ishikawa, K. (1966). Personal communication. Angiology, 12, 357. Jacquet, G. H., and Meyer-Burgdorf, G. (1960). Chirurg., 31, 481. Jacquet, G. H., and Meyer-Burgdorf, G. (1960). Lambley, D. G. (1963). Brit. med.

McEvedy, B. V. (1962). Brit. 尹. Surg., 49, 585.

Mentha, C. (1965). Ұ. Chir. (Paris), 89, 173.

(1966). Personal communication. 
Parkes, A. (1961). F. Bone 7t Surg., 43B, 784.

Patel, J. (1966). Personal communication. and Cormier, J. M. (1963). Presse méd., 71, 244. Facquet, J., and Piwnica, A. (1958). Ibid., 66, 1164

Rains, A. J. Harding (1966). Personal communication.

Robb, D. (1960). Brit. F. Surg., 48, 221.

Simon, R. (1963). Mém. Acad."Chir., 89, 849.

Sutton, D. (1962). Arteriography, p. 84. Edinburgh and London.

Tytgat, H., Derom, F., and Galinsky, A. (1958). Acta chir. belg., 57, 188.

\section{Addendum: Amino-acid Analysis of Protein Present in a Popliteal Artery Cyst}

\section{G. LEAF,* M.SC., PH.D.}

The gel obtained from the cyst in Case 2 was stored frozen at $-20^{\circ} \mathrm{C}$. A portion was analysed by the microKjeldahl method and found to contain $0.52 \%$ nitrogen, corresponding to a protein content of approximately $3 \%$. The remainder of the gel was lyophilized and $3 \mathrm{mg}$. of the dried material was hydrolysed with $1 \mathrm{ml} .6 \mathrm{~N} \mathrm{HCl}$ in an evacuated sealed tube at $115^{\circ} \mathrm{C}$. for 20 hours. Hydrochloric acid was removed from the hydrolysate in a rotary evaporator and the residue analysed for aminoacids by Piez and Morris's (1960) modification of the method of Spackman, Stein, and Moore (1958). The results are shown in the Table, where they are compared with values for collagen from human tendon (Eastoe, 1955) and elastin from bovine aorta (Gotte, Stern, Elsden, and Partridge, 1963). The absence of hydroxyproline and hydroxylysine from the hydrolysate was confirmed by paper chromatography with the use of butanol/acetic acid/water $(4: 1: 5)$ and water-saturated phenol as solvents and both ninhydrin and isatin as staining reagents. The paper chromatograms confirmed the presence of substantial amounts of glucosamine.

* Institute of Biochemistry, University of Glasgow.
It will be noted that the amino-acid composition of the protein differs markedly from that of a representative collagen, and the failure to detect hydroxyproline suggests that neither collagen nor elastin could be present in more than traces. The

Amino-acid Composition of Protein from Popliteal Cyst Compared with Those of Collagen and Elastin

\begin{tabular}{|c|c|c|c|c|c|c|}
\hline & & & & Cyst Protein & Collagen & Elastin \\
\hline $\begin{array}{l}\text { Aspartic acid } \\
\text { Threonine } \\
\text { Serine . . } \\
\text { Glutamic acid } \\
\text { Proline . . } \\
\text { Hydroxyproline } \\
\text { Glycine .. } \\
\text { Alanine . . } \\
\text { Cystine . . } \\
\text { Valine } \\
\text { Methiunine } \\
\text { Isoleucine.. } \\
\text { Leucine . . } \\
\text { Tyrosine . } \\
\text { Phenylalanine } \\
\text { Lysine . } \\
\text { Histidine . } \\
\text { Arginine .. } \\
\text { Glucosamine } \\
\text { Hydroxylysine }\end{array}$ & 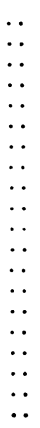 & 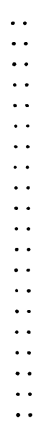 & 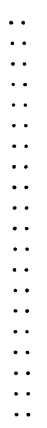 & $\begin{aligned} 38 \cdot 4 \\
24 \cdot 4 \\
23 \cdot 2 \\
52 \cdot 9 \\
23 \cdot 6 \\
0 \\
87 \cdot 0 \\
41 \cdot 0 \\
19 \cdot 0 \\
29 \cdot 0 \\
4.3 \\
6 \cdot 4 \\
32 \cdot 3 \\
11 \cdot 2 \\
18 \cdot 8 \\
42 \cdot 3 \\
9.5 \\
19 \cdot 9 \\
29 \cdot 2 \\
0\end{aligned}$ & $\begin{array}{r}50 \cdot 5 \\
19 \cdot 3 \\
38 \cdot 5 \\
75 \cdot 5 \\
127 \cdot 2 \\
96 \cdot 2 \\
338 \cdot 0 \\
115 \cdot 6 \\
0 \\
26 \cdot 5 \\
6 \cdot 0 \\
9 \cdot 5 \\
27 \cdot 2 \\
3 \cdot 8 \\
14 \cdot 8 \\
22 \cdot 5 \\
5 \cdot 6 \\
51 \cdot 2 \\
9 \cdot 3 \\
9.5\end{array}$ & $\begin{array}{r}15 \cdot 6 \\
13 \cdot 4 \\
10.5 \\
23.1 \\
117.3 \\
11 \cdot 4 \\
318.7 \\
223.6 \\
0 \\
136.7 \\
2 \cdot 0 \\
30.5 \\
67 \cdot 2 \\
12.7 \\
36 \cdot 4 \\
8.2 \\
1.9 \\
9.8 \\
= \\
-\end{array}$ \\
\hline
\end{tabular}

Values are expressed as $\mu$ moles amino-acid per $10^{5} \mathrm{~g}$. dry matter for the unknown protein and $\mu$ moles per $10^{5} \mathrm{~g}$. protein for collagen (human tendon, Eastoe, 1955) and elastin (bovine aorta, Gotte et al., 1963).

presence of glucosamine and the fact that the amino-acids recovered account for only $53.6 \%$ of the dry matter suggest that the main constituent may be a mucoprotein. There was insufficient material to investigate this matter further.

\section{REFERENCES}

Eastoe, J. E. (1955). Biochem. F., 61, 589.

Gotte, L., Stern, P., Elsden, D. F., and Partridge, S. M. (1963). Ibid., $87,344$.

Piez, K. A., and Morris, L. (1960). Analyt. Biochem., 1, 187.

Spackman, D. H., Stein, W. H., and Moore, S. (1958). Analyt. Chem., 30, 1190 .

\section{Medical Memoranda}

\section{Chronic Thyrotoxic Myopathy with Involvement of Respiratory and Bulbar Muscles}

Brit. med. F., 1967, 3, 415-416

Numerous reports of chronic thyrotoxic myopathy have followed Bathurst's (1895) original description. The incidence of respiratory and bulbar muscle weakness in previously reported cases was extremely rare ; furthermore, in most of these cases the diagnosis could be challenged because of lack of proper documentation or correct interpretation. In a review of the condition by Whitfield and Hudson (1961) the respiratory and bulbar muscles were not mentioned, and in a reappraisal by Havard (1962) it was stated that these muscles are little if at all affected.

This report describes a case of chronic thyrotoxic myopathy in which weakness of the respiratory and pharyngeal muscles was a prominent feature.

\section{CASE REPORT}

An 83-year-old man was admitted to hospital with nine months' history of progressive loss of weight, generalized weakness and lassitude, shortness of breath on exertion, and difficulty in swallowing.
During that period he was investigated elsewhere but no definite diagnosis was made. Initially he was described as being thin, but he looked fit and active and no abnormal physical signs were noted. Three months before admission he developed oedema of the ankles and distension of the neck veins; he was treated for congestive cardiac failure but his condition continued to deteriorate.

When first seen in hospital he had lost 3 stones $(19 \mathrm{~kg}$.) in weight. $\mathrm{He}$ was dyspnoeic at rest and so weak that he had difficulty in rising from the sitting or lying position; he was unable to swallow solid food and had difficulty with liquids.

On examination he looked emaciated and ill. The pulse was regular at 90 a minute, was collapsing in character, and the blood pressure was $160 / 60$. The apex beat was forcible but not displaced. The jugular venous pressure was raised and he had oedema of the ankles. Chest expansion was poor and there were a few scattered rhonchi in both lung fields. The liver and spleen were not palpable. The striking findings were confined to the neuromuscular system, which showed profound weakness and wasting of the proximal and distal muscles of the limbs and of the trunk muscles. There were no fasciculations and the tendon reflexes were normal. The cranial nerves were intact and there was no sensory loss.

The thyroid gland was not enlarged and no thyroid bruit could be heard. There were no eye signs, apart from a slight lid lag. His hands were warm and he had fine tremors of the outstretched fingers.

Investigations.- $\mathrm{Hb} 14 \mathrm{~g} . / 100 \mathrm{ml}$; white cell count 5,000/ cu. mm. ; E.S.R. $22 \mathrm{~mm}$. in one hour (Westergren) ; blood urea $47 \mathrm{mg} / 100 \mathrm{ml}$. Serum electrolytes, liver-function tests, and 